\title{
Governance structure and transaction cost: relationship between strategy and asset specificity
}

Christian Luiz da Silva Professor da UniFAE Maria Sylvia M. Saes Professora da FEA/USP

\section{Key words}

governance structure, transaction cost, strategies.

JEL Classification B25, D23, $\mathrm{R} 30$.

\section{Palaviras-chaves}

estrutura de governança, custo de transação, estratégias.

Classificação JEL B25, D23, R30.

\section{Abstract}

This article presents a theoretical discussion of the determining factors of governance structures, using the transaction cost approach. The coexistence of distinct structures in the same production chain, whose assets show no difference in terms of specificity, is a problematic challenge for transaction cost economics, since it predicts a convergence towards the most efficient structures. The research is pure and explanatory and seeks to identify the determining or contributing variables to the occurrence of the phenomena. Thus, the research source is documental, encompassing the literature discussing the relation between governance structure and transaction cost.

\begin{abstract}
Resumo
O objetivo do artigo é discutir teoricamente quais os fatores que determinam as estruturas de governança a partir da abordagem dos custos de transação. A coexistência de estruturas distintas numa mesma cadeia de valor, em que os ativos não apresentam diferenças em termos de especificidade, é uma importante problemática para a Economia dos Custos de Transação, que prevê uma convergência para as estruturas mais eficientes. A pesquisa é pura e de nivel explicativo e pretende identificar os fatores que determinam on que contribuem para a ocworrência dos fenômenos. Desta forma, a fonte de pesquisa é documental, abrangendo bibliografias e artigos que discutem a relação entre estrutura de governança e custo de transação.
\end{abstract}




\section{1_ Introduction}

In 1937 Ronald H. Coase changed the way people saw economic organizations when he published "The Nature of the Firm" (1937). Half a century later, Williamson and Winter (1993) published a collection of writings shedding new light on contemporary issues and creating tools that allowed Coasean ideas to be tested. Their discussion focused on the search for economic efficiency. Transaction costs were the explanatory basis for the way in which economic relations were organized. Since then several authors, including Williamson, have reviewed and applied the core concepts of Transaction Cost Economics (TCE). The controversial definition of transaction costs permeates the governance mode among economic actors.

The original model conceived by Williamson (1991) analyzes the governance modes, seen as the results of the search for gains through the choice of cost-minimizing factors, basically as a function of the transaction dimensions (asset specificity, uncertainty and frequency). Joskow (1993) emphasizes the difficulties in data collection and the problems of measurement in empirical research, which caused theoretical testing to progress only very gradually. Empirical evidence allowed Joskow (1993) to restate his proposition that the governance of contractual relations systematically varies according to the degree of asset specificity. However, the author highlights the fact that there are factors that relativise the univocal integration trend directly related to the existence of the high specificity of the assets. In this sense, the cost transaction discussion and its relation to the definition of governance structure are at the core of the Coasean debate. Thus it is relevant to revisit the literature and some empirical proof to assess which factors determine the governance structures.

The aim of this article is to present a theoretical investigation of the factors determining the governance structures using the transaction cost approach. The coexistence of different structures in the same value chain, whose assets are not different in terms of specificity, is an important issue for Transaction Cost Economics, since it predicts a convergence toward the most efficient structures.

The research is pure and explanatory, since it seeks scientific 


\footnotetext{
1 The way the interaction among agents is organized; fundamental behavior rules, which the agents incorporate towards their competitors, clients, suppliers, employees, officials, etc.; ways and degrees of direct exercise of discretionary power exerted by actors alien to the market, for instance, regulatory authorities, judges, etc., which contribute to the formation of the firms' organizational and behavioral patterns.
}

advances and intends to identify the determining or contributing factors to the occurrence of the phenomena. Thus, the source of the research is documental, encompassing literature on the relation between governance structure and transaction costs. The participatory observer method was also used in the research and in study cases on agro-industrial chains carried out for the last five years (Pensa and Ipardes).

Besides this introductory section, the article encompasses four more sections. The second section poses the problem to be discussed in the article. The third section analyzes Williamson's model. In the forth section,

Williamson's model is reanalyzed with a view to understanding the possibility of coexistence of governance structures in production chains with similar assets, under the perspective of the New Institutional Economics. This problem is approached through the analysis of both the markets of the firm and interdependence among production strategies. The study of the Brazilian poultry chain illustrates such considerations. Finally, the fifth section presents conclusions and raises new problems for future discussion.

\section{2_Problem posing}

Espino (1999, p. 293) defines governance structure as an organization's internal rules devised to guide its daily transactions, i. e., the interactions among individuals within the organization and its relations with other organizations. He established that organizations are ultimately institutional arrangements and characterizes them, based on Dosi (apud Espino, 1999, p. 294), as
formas de organización de las interacciones entre agentes; reglas fundamentales del comportamiento, que los agentes incorporan, hacia sus competidores, clientes, proveedores, empleados, autoridades gubernamentales, etcétera; formas y grados de ejercicio directo de poder discrecional ejercido por actores ajenos al mercado, por ejemplo autoridades reguladoras, jueces, etc., que contribuyen a la formación de los patrones de organización y comportamiento en las empresas. ${ }^{1}$

Williamson (1996) associates the concept of institutions with that of governance for micro analyses of the individual transaction. The institutional environment (rules of the game) is taken as granted, and the economic players willfully align transactions with governance structures to optimize 
revenues. Thus, institutions are governance mechanisms and their study is directly related with the optimum decision regarding lower transaction costs.

Arrow (apud Williamson, 1996, p. 5) defines transaction costs as "costs of running the economic system". Based on this concept, Williamson states that the choice of governance mode is made through a comparison of the costs of one governance mode with those of others. In this sense,

\section{the study of governance is concerned with the identification, explanation, and mitigation of all forms of contractual hazards (Williamson, 1996, p. 5).}

The contractual issue is at the core of the debate on the costs of running a transaction (Coase, 1972). Such issue contributes toward the progress of the Theory of the Firm, inasmuch as it points out other relevant determinants of the firm's productive efficiency. For Williamson, the contract is a complex institutional arrangement involving the different aspects of an economic transaction (basic unit of an economic relation), such as planning, promises, competition and governance (Williamson, 1985, p. 30).
The existence of distinct dynamics within the internal logic of the transactions translates into a complex puzzle of theoretical and empirical knowledge. These internal divergences of the transaction are understood through the attributes that lead the economic agents to negotiate. Based on the TCE, Zylbersztajn (1995, p. 137) infers that

$$
\begin{aligned}
& \text { the prevailing governance structures are } \\
& \text { the optimizing result of the alignment of } \\
& \text { characteristics of the transactions and of } \\
& \text { the institutional environment. Thus } \\
& \text { optimization is seen in the neoclassical } \\
& \text { style, meaning search for efficiency. }
\end{aligned}
$$

Therefore, it is possible to make a Darwinian assumption that an efficient governance structure should prevail as a winning structure. And it is a fact that there is a process of expelling inefficient structures - which may last until the result is achieved. The path dependence may allow for the persistence of inefficient structures. The necessary time for the most efficient structure to win would depend on a series of factors, among which is asymmetric or incomplete information or even institutional rules - formal or informal - that prioritize certain structures. 
Here, we can ask, "How does ECT define the choice of the organizational structure?" According to Williamson (1975) and to Klein, Crawford and Alchian (1978) different governance structures reflect inherent transaction attributes. Efficient, cost-minimizing structures result from their alignment with the transaction attributes (frequency, uncertainty and asset specificity), considering the agent's behavioral presuppositions (bonding rationality and opportunism).

A degree of asset specificity would be the main attribute of the transaction used to explain a firm's governance strategies. Specific assets are those that are non-utilizable in another activity or by another agent, except with loss of value. The more specific the asset the more the firm will internalize the transaction via vertical integration. Klein, Crawford and Alchian (1978) argue that whenever the asset becomes more specific, the cost of hiring generally increases more than that of vertical integration. The basic idea is that a firm appears in situations where it is not possible to draw up good contracts and where it is important to allocate power (Hart, 1997).
Therefore, the specificity of the assets is considered as one of the main elements that can explain the transaction costs. The second dimension to be considered in the analysis of the transactions is the frequency, $i . e$., the repetition of the same kind of transaction, whose importance is seen in the dilution of costs for the adoption of complex mechanisms throughout several transactions, as well as in the formation of a reciprocal reputation among agents. This concept is also used by Klein, Crawford and Alchian (1978) and Kreps (apud Azevedo, 1996, p. 26) who consider that the cost of an opportunistic action is determined by the present value of the future flow of resources involved in the bilateral relation.

The third dimension is uncertainty, which involves the understanding that it is impossible to foresee future events, $i$. e., the contractual arrangement cannot ex-ante establish price, delivery dates, quality and acceptance of the goods negotiated. Therefore, no contract is complete. Thus an opportunistic action from one of the parties is possible: the costs associated with such an action are the transaction costs. 
Most empirical works focusing on transaction costs try to confirm the thesis of the alignment of the governance structures - market, contract and vertical integration resulting from the intensification of the transaction costs (Joskow, 1993). They also try to demonstrate that asset specificity is one of the most important determinants of the three transaction attributes. This means that whenever the investment in specific assets increases, the cost of performing a market transaction increases more than that of a transaction in more complex structures, thus reaching vertical integration (Willianson, 1985).

Ménard (2000, p. 248) relates the definition of the type of governance structure to enforcement procedures. This relation highlights two defining factors to explain the prevailing structure: asset specificity and uncertainty level. The author states that many empirical works suggest that asset specificity determines the governance structure and related arrangements, whereas the uncertainty is said to be what most influences contracts and their relation to enforcement procedures. That question ratifies the asset specificity as a determinant, but it shows that another transaction attribute-uncertainty- can be a determinant in the contractual relation established, i. e., in the full governance mode of the relation among the parties.

However, neither the traditional nor Ménard's approach can explain the coexistence of different governance structures if the same asset specificity is considered in an agro-industrial system. The challenge is, therefore, to understand this phenomenon within the scope of the Coasean proposal.

\section{3 - Definition model of the governance structure: Williamson's View}

Williamson's analysis (1985) departs from the perspective of comparative static by positing a model that relates the degree of asset specificity to the governance mode cost. The author considers that the decision on how to organize production systems is conditioned by a degree variation in the specificity of the asset involved.

Figure 1 shows a relation between asset specificity and governance mode cost. It can be verified that the governance structures are distributed in three different ways, 
two extreme ones, hierarchy and market, and an intermediary one, the hybrid mode. The higher the asset specificity involved, the higher the cost of its market monitoring. Thus the governance mode can be altered towards a hybrid mode, as seen at point $(A)$, at which monitoring costs by the market are higher than in the hybrid mode. In the mixed or hybrid mode the existence of contracts enabling the system to be "almost verticalised" is verified. If the monitoring costs become so high as to make this governance mode inviable, the transaction then forces the system to be managed under the hierarchic mode, as seen at point $(B)$, necessarily using internal organization to coordinate it.

\section{Figure 1_Governance mode costs and asset specificity degree}

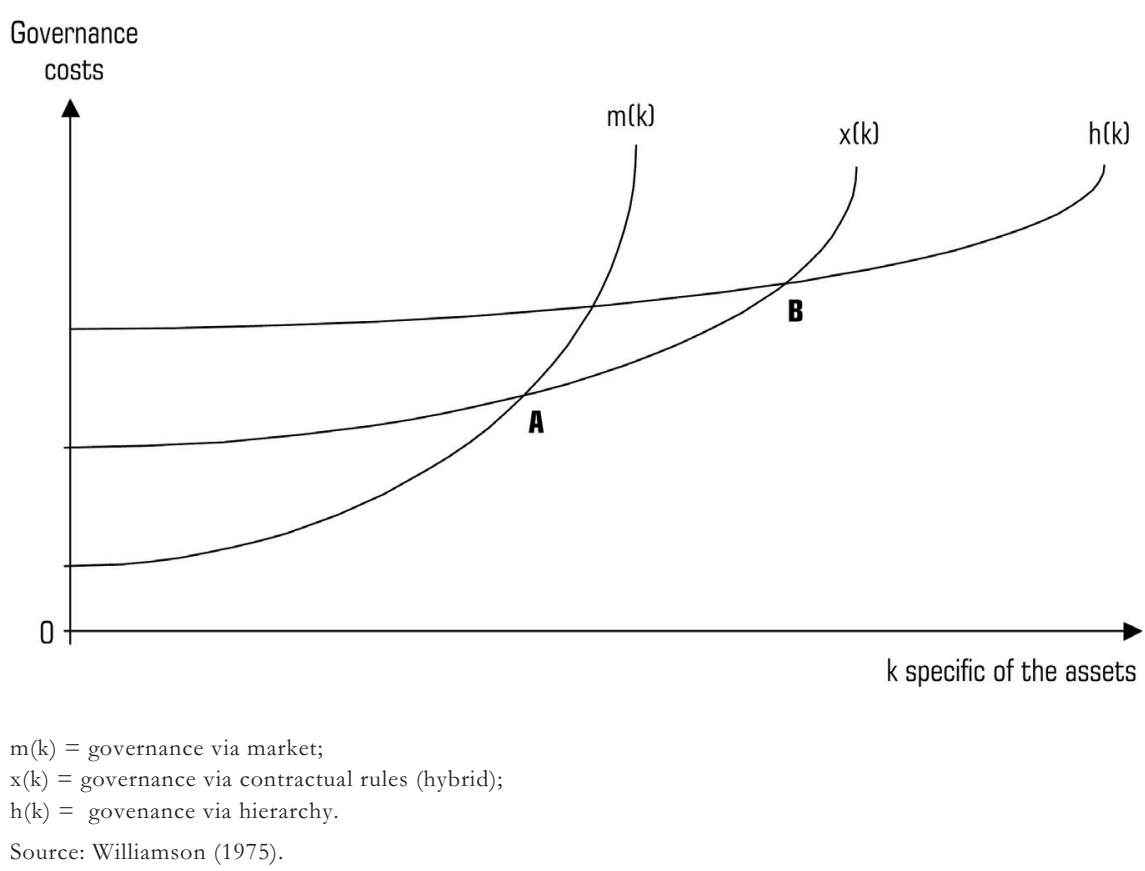


The hierarchy is characterized by internal organization (vertical integration). For Williamson (1985), while incorporating a transaction, the internal organization increases the firm's power to impose itself on the structure of the production system. The adoption of the hierarchy occurs when the costs of this governance structure are inferior to those obtained via the market.

The governance structure characterized by vertical integration is mainly determined by the characteristics of the specific assets used in the chain. The higher the asset specificity, the larger the prizes given by the adoption of the hierarchy as a governance mode. The advantage of the latter vis-à-vis market organization lies in its better capacity to adapt to environmental change conditions.

The type of contract used in this mode is relational, with more flexible transactions and with the possibility of a continuous negotiation, in which adjustments are permanent and on-line and, consequently, in which the original contract is no longer an exclusive basis for negotiations (Macneil apud Jank, 1996, p. 35). The adoption or intensification of the hierarchical mode requires increased bureaucratic costs and decreased incentives from the market to the agents (Zylbersztajn, 1995 , p. 141). If these costs are higher than the benefits arising from the other modes, such a situation enables the adoption of either market or hybrid governance modes.

However, when considering the governance mode as an element that explains the Theory of Contracts, Williamson (1985) accepts that this definition of the optimal structure is not so biased in an economic transaction because contracts thereof tend to be incomplete. Brousseau and Fares (2000, p. 410) state that

$$
\begin{aligned}
& \text { Agents therefore design incomplete } \\
& \text { contracts that are not implemented and } \\
& \text { are ex ante designed as a complete set of } \\
& \text { (possibly contingent) behavioral rules } \\
& \text { that will ex post solve all coordination } \\
& \text { problems. Instead, they design } \\
& \text { decision-making devices that ex post will } \\
& \text { indicate the behavior required by } \\
& \text { contractors to ensure the most efficient } \\
& \text { coordination and the guarantee the } \\
& \text { enforcement of mutual commitments. }
\end{aligned}
$$

Thus the decision making process in a transaction will derive from the contractual parties, which can be vertically (hierarchically) integrated, and based either on negotiation (hybrid) or 
2 A scope economy is considered as a cost reduction based on production line diversification. This diversification can occur with totally different products or with products within the same chain with an aggregation of differentiated value. on a third party (market). Ex ante a transaction, there is a set of rules and there are authorities established by the governance mechanisms. Brousseau and Fares (2000, p. 410) verify that authority and enforcement belong to the inherent nature of the governance structure, and that its definition is associated with the capacity of the agents that deal with such coercion mechanisms in the transaction. Such arguments call for a new discussion of Williamson's model, and a verification of its methodological limitations to define the governance structure as a tendency to seek efficiency in the transaction.

\section{4_Rediscussing Williamson's Model}

Zylbersztain (1995, p. 83) points out an important restriction to Williamson's model when he states that if, in a first moment, scale and scope ${ }^{2}$ economies are negligible, there is a limited possibility that other decision elements exist, regarding the integration of a certain production step. In this sense, there are variables only for the costs of production and of organizing the information and the resources required in the process of making the product. There is no alternative for new allocations of resources, since the firm is limited to a non-existence of economies of scope, and since it is based on the definition of already strategically chosen products (beyond the definition of what and for whom to produce; the definition here is only how to produce).

Thus, the total cost is the sum of the production cost and the governance cost, the latter referring to administrative and bureaucratic costs. Initially, the governance cost has to be examined as a variation between the bureaucratic costs associated with the internalized production and the governance mode via market (Equation 1). Within these limits exposed, this cost is only related to the specificity of the assets. For instance, if the specificity is low, the organization will have high adaptability in the social environment. That decreases the costs of managing resources and, consequently, makes the governance cost via market lower than the hierarchic $(\Delta G>0$, ) cost. As Zylbersztain points out (1995, p. 83), if the hierarchic governance cost $(\mathrm{B})$ is higher than that of the market (M) "this means that with lower degrees of asset specificity the market is more efficient than the firms 
in terms of transaction costs, since it avoids bureaucratic costs". On the other hand, when the adaptation to the environment becomes more difficult, uncertainty becomes more preeminent and greater adaptation of the firm to external changes is necessary. Here, the governance costs via market (M) become higher than the hierarchic costs (B), because the relative costs to control and adapt the organization to environmental changes become lower than those relative to the free market. There is a limitation regarding the change of the type of governance structure involving the balance between the costs adapting to the environment and to the firm $(\Delta G=0)$. In this sense, the higher the need to adapt through the organization, the higher the need for controls and bureaucracy and,

therefore, $\Delta G$ tends to zero. From this moment on, the more uncertainty becomes preeminent, and the more adaptation is demanded by the firm, the more the option for hierarchical governance is consolidated (bureaucratic and internal control).

$\Delta G=B(k)-M(k)$

where: $\Delta G=$ Governance cost variance;
$B(k)=$ cost of governance hierarquical as a function of the specificity of the asset; $\mathrm{M}(k)=$ cost of governance through the market as a function of the specificity of the asset.

Once the constraint to the economy of scale is eliminated, it is necessary to take the production costs into account. At a given moment, it can be advantageous for the firm to have governance via market, but the firm would not profit from scale economies if its processes were hierarchic (or vice-versa). Thus, it is necessary to assess the total cost as the sum of the gains by the production cost (scale) and of the governance (bureaucratic) Equation 2.

For Williamson (1985), both costs are associated with the type of asset used and, therefore, the decision regarding the best governance structure will rely on the combination of scale and bureaucracy in its evolutionary process. The limit between the definition of structure will occur when the governance costs and the total costs are null. If such values are inferior to zero, then the prevailing governance structure will be the hierarchic one, due 
to the higher need for adaptability by internal controls and by scale economies.

$C T=[C i(k)-C m(k)]+[B(k)-M(k)](2)$

where: $C T=$ total cost;

$C i(k)=$ hierarchical cost of production as a function of the specificity of assets; $C m(k)=$ cost of production through market as a function of the specificity of assets; $B(k)=$ hierarchical cost of governance as a function of the specificity of assets;

$M(k)=$ governance cost through market as a function of the specificity of assets.

The Williamson model is strongly criticized for three reasons. The first two come from Demsetz (1993) and Barzel (1997); they include the cost of information as an important element to define the governance structure. North (2005) points out that the persistence of heterogeneous governance structures may be a result of factors such as institutional path dependency.

Demsetz's criticism (1993) is based on the analysis of profit maximization or the efficiency in the replacement of the firm by the market which occurs if the cost of using the market becomes relatively higher that the cost of the hierarchy. That means that the extension of the firm will be that one defined by the equality among the marginal values of the transaction costs and those of the hierarchy. According to the author, the cost of information is what will define the governance structure adopted. Thus, to understand its existence it must be recognized that the hierarchy is a resource employed in a world where knowledge is incomplete and obtained at a high cost.

The author contends that internal production does not mean a clear elimination of the transaction cost. Likewise, the purchase of goods from another firm, instead of internal production, implicitly involves another firm's administration costs (of the hierarchy), so that hierarchical costs are not eliminated when goods are purchased through the market. The administration (hierarchy) will be working in a more disperse manner among many firms. Even if each firm is an individual entity, administration costs exist: those of planning and carrying out tasks. Besides, it is not correct to infer that production would become individualized if the transaction cost were zero. 
The independent individual or cooperative production through the firm will depend upon on the extension of the economies of scale (scope) and on the hierarchy. The degree of decentralization will not depend only on the transaction cost, because this is not the only cost the firm will take into consideration. There are many other costs, including that of production. Thus, to say that firms produce their own inputs when they are cheaper does not mean that the transaction costs are lower than those of administration (hierarchy). An increase in the transaction cost does not lead to a replacement of the market coordination with the administration (hierarchy), but to a replacement of the hierarchical coordination in small firms (higher quantity) with another type of coordination in larger companies (lower quantity).

For it, the emphasis given to the cost of transaction implicitly assumes that all firms can produce goods with the same facility. The market is seen as a perfect replacement in a firm's production when the transaction cost in the market is compared to that of hierarchy within the firm. This analysis implicitly presupposes that information has no cost for the purpose of production. That means that what a firm can produce another firm also can, so that the decision to buy or to produce depends on the differences in the transaction costs. ${ }^{3}$

Demtsez (1993, p. 165) posits that each firm is a bundle of commitments to technology, personnel, and methods, all contained and constrained by a insulating layer of information that is specific to the firm, and this bundle cannot be altered or imitated easily or quickly. The components of this bundle that are emphasized by transaction cost theory are important, but not exclusively so.

The transaction cost plays an important role determining how the firm is formed, but its vertical limitations depend on the productivity that will be reached according to different arrangements. Particularly important in the determination of the benefits of the cooperative production are the considerations based on knowledge. Continuous association of the same persons facilitates the accumulation of information by the firm (gains of scale) and by the persons (specificity of the human capital). Thus the limitations of the vertical integration of a firm would be
3 It is worth noting that

Williamson mentions

the need to consider production costs in the analysis, but he highlights that he wants to emphasize transaction costs in his model. 
determined by the economy of conservation of the expenditures on knowledge. A single firm - vertically integrated-would find it difficult to acquire and keep the necessary knowledge archives to control the cost and the quality to make good managerial decisions if their uses were multiple.

Another line of the analysis focusing on information for the understanding of the firm's configuration is found in evolutionary theory. Winter (1993) holds that the firm in this approach is seen as a repository of productive knowledge, which involves the idiosyncratic characteristics that distinguish it from superficially similar firms in the same line of business.

The evolutionary theory suggests that the concept of asset specificity is important to understand the working of the firm as a repository of knowledge. This theory emphasizes that the firm possessing an established routine has resources that can be used with great profit. Thus, the firm works as a repository of knowledge mainly due to the time necessary to associate the inputs, particularly those regarding human services, with the firm. The costs and benefits arising from the adjustment define a specific mode of governance which is constantly influenced by the pattern of transaction in force. Thus the process of changing the way things are done in a firm involves incremental adjustments in a complex independent system.

Naturally, the market supplies the information that guides the firm's strategy and global profitability.

It is thus necessary to understand the factors favoring firms by opposition, examining others that present lower performance or those that merely copy success. The concept of asset specificity is fundamental to understand the working of the firm as a repository of knowledge and its growth. But it is also necessary to ally such analysis with a wider concept, in which the environments of the transaction must be characterized so that they can give a basis for the analysis of the types of routines of the transactions that are viable in different environments.

The second criticism of the view of Williamson's approach originated in Barzel (1997). The author states that the Williamsonian focus is not general, but rather, it is contained within a wider theoretical model whose information is the general variable that explains the 
existence of the transaction costs. For the author, transaction costs are costs associated with the transfer, capture and protection (maintenance) of the rights. Given that a transaction involves several dimensions and that for this reason it is complex, there are costs that are hard to measure. Barzel affirms that the concept and measuring of transaction costs is more complex than that proposed by Williamson and the definition of governing structure is dependent on other elements besides the specificity of assets.

Transaction costs will exist when there are information problems, regardless of the existence of specific assets. Thus, even if the degree of asset specificity is very high, there would be no need for vertical integration if the initial rules for contracting were transparent and the distribution of the quasi rent, i.e., of the rights to the property of the income generated, were well defined. However, if there were a large variability in the income generated and difficulty measuring it, one of the parties could capture that income, which would bring high costs for monitoring and protecting rights. This means that when the residual rights to the asset, which is shared by those participating in the relation, are not constant, then there is a mutual effort to capture the biggest part of this indefinite fraction of the income. Therefore, the maximization of the net value of an asset involves property and the pattern of property. In this way, the pattern of property will be defined by the variability in the assets' value. Thus, integration acquires a relevant role in the definition of the governance structure when there is a situation of high uncertainty of information and prohibitive costs to delineate rights. On the other hand, when the rights are perfectly delineated and there is no cost to obtain information about the product, the relevant transaction cost will be zero.

According to this point of view, Williamson's model only partly explains the real motivation to integrate. It is not difficult to ensure the rights to an asset when the flow of services it generates can be promptly verified, because it is relatively simple to impose a charge commensurate with the level of service transacted. Whenever the flow of service is known and constant, there are no costs to ensure the rights to the assets. If it varies, but is predictable, the rights are also ensured. Naturally, the 
variability can reduce the value of the assets, but it does not necessarily affect the certainty of the possession of the rights. However, when the flow of the income of the transacted rights is subject to random fluctuations and both parties can profit from that, then the delineation of the rights is problematic.

Thus, if the degree of asset specificity is the same, Barzel's approach can suggest an important argument for the coexistence of different governance structures in a production chain: the difficulty of measuring information. This means that, in opposition to the Williamsonian view, when the same asset specificity is considered in a production chain, the coexistence of governance structures would not be only transitory. Also, it does not mean that we would be at the indifference point between a governance structure and another one, like at A or B in Figure 1. Rather, it means that there would be a region of indifference between one or another situation because of the difficulty measuring information among the different production chains, i. e., despite the same degree of asset specificity, the conditions of uncertainty or of difficulty of measurement would lead to the coexistence of different governance structures.
In his defense of empirical studies focusing on the issue of firm configuration based on the role of specific assets, Joskow (1993) posits that their approach was due to their capacity for instrumentation. However, the author contends that there is no unified theory. Several economic characteristics will thus influence the decision of whether the firms will become integrated or not.

The works of Muris, Scheffman and Spiller (1992) follow this line of thought. They have observed that investments in specific assets in the soft drinks industry in the US were important for the initial configuration of the firm's governance structure. The alteration in the governance structure, from the time the distribution channel was employed to the mode of vertical integration, was caused by changes in the market configuration.

Thus, since there were no changes in the specificity of the asset, the firms adopted the strategy of a more complex governance structure because they needed a higher level of regional information about the demand. The efficiency in Williamson's and Barzel's views must be particularized according to the type of demand the firm meets. Thus it is possible to have 
the same production system meeting different demands, which makes the existence of more than one type of efficient structure possible.

The last criticism refers to the importance North gives to path dependence to explain the persistence of governance structures. According to the author, economic performance is determined, to a great extent, by the type and quality of the institutions that give support to the markets. North (2000, p. 37) defines institutions as a structure that is imposed by humans upon themselves to facilitate interaction. Corroborating with North, Langolis states, exemplifies and questions:

\section{But what happened in the century between the railroad and the Internet? Why did high levels of verticalization persist until the late twentieth century, long after the passing of the original entrepreneurial design problem that gave rise to most of these firms? The answer has to do with path dependency and the nature of the selection environment. (Langlois, 2005, p. 28)}

This indicates that the decision may be the technical consistency and efficiency of the chain seeking optimization of resources, but the way humans interact over time and the institutions that permeate and influence them may be decisive in strategic decisions, like the type of governance structure adopted.

Stemming from the criticism, it can be observed that the definition of the governance structure is more complex than if it is considered a function of the specificity of assets. The authors discussed here emphasize that information and the decision making context may also be important elements to understand the type of governance structure in a chain. These two variables will be amplified to strategies and the influence over the governance structure will be evaluated.

Therefore, it is possible to frame a hypothesis referring to the coexistence of governance structures. This means that the coexistence of distinct governance structures would be centered on the strategic issue of each group of firms meeting different market needs. In order to discuss this hypothesis this study will evaluate: the importance of the strategic axis for the definition of a governance structure starting from the influence of the type of market served (and the coexistence of markets with the same production structure); and the interdependence between the production strategy and commercialization. 


\section{1_ Markets Served}

The decision concerning the type of governance structure based on Williamsom's approach considers the direct relation between asset specificity and total costs. However, a firm's economic efficiency must be also determined by the optimization of the use of its resources per market served. In some cases, the same asset can enable the firm to meet different market segments. For instance, the poultry market can meet the demand for whole broiler or broiler cuts using the same production technology.

Such a possibility decreases the asset specificity, but not the firm's capacity for adaptation and internal control and its control of the environment. In this aspect, this consideration eliminates the second restriction to the Williamsonian model (present in Equations 1 and 2). It also emphasizes the need to evaluate the economy of scope to define the type of governance structure. Therefore, there will be governance costs distributed among the manufactured products. As for the production costs, they can be lower in virtue of the existing economy of scope. Equation 3 shows that the total cost will be distributed among manufactured products. If the total cost is lower than the sum of the costs of each individually manufactured product without the appropriate synergies relative to the economy of scope $(C t a, b<C t a+C T b)$, there can be a new configuration of governance.

$$
\begin{aligned}
C T_{A, B} & =\left[C i_{A}(k)-C m_{A}(k)\right]+ \\
& +\left[C i_{B}(k)-C m_{B}(k)\right]+ \\
& +B_{A, B}(k)-M_{A, B}(k)
\end{aligned}
$$

where: $C T_{A, B}=$ total cost of products $A$ and $B$ $C i_{A}(k)=$ cost of production of product $A$ hierarquical as a function of the specificity of the asset. $C m_{A}(k)=$ cost of production of product $A$ through the market as a function of the specificity of the asset. $C i_{B}(k)=$ cost of production of product $B$ hierarquical as a function of the specificity of the asset.

$C m_{B}(k)=$ cost of production of product $B$ through the market as a function of the specificity of the asset.

$B_{A, B}(k)=$ cost of hierarquical governance as a function of the specificity of the asset. $M_{A, B}(k)=$ cost of governance through the market as a function of the specificity of the asset. 
As seen in equation 3 , the total cost will be a function of the individual production costs and the governance cost that has synergy (bureaucracy optimized with the increment of new products), as observed in Winter and Demtsez. Each product will have its own basic governance cost, but part of this cost is common to more than one product, which allows for a reduction of the same insofar as it aggregates new products (thus configuring the economy of scope). Thus, the governance cost at a $t_{1}$ moment is not a ratio between the governance cost at $t_{0}$ because of the amount of product diversification (two products would imply half the governance cost for each one). Part of the governance cost is duplicated and thus the reduction of this cost is not very significant, event though it exists.

With this reduction, the quantity of assets to shift the market governance to the hierarchic mode happens at a previous level of specificity $\left(k_{1}<k_{0}\right)$. In this sense, it is possible to infer a tendency to change the governance structure based on the existence of the economy of scope. The latter can result from a strategic definition of the firm and from the level of information it can obtain from the markets being analyzed. On the other hand, if the total cost of the scope $(C T a, b)$ is higher than the sum of the costs of each individual process, it is necessary to decide which market to participate in (loss reduction by scope) or which governance to adopt. Thus, the evaluation of the relation between the choice of the production scope and the type of governance is not so evident because it will depend exclusively on the existence of economies of scope. This tends to happen mainly in processes with significant economies of scope. To evaluate such economies, it is necessary to reanalyze issues such as market functioning, product type, competitors, demand characteristics and market size and to turn all these data into market information. The higher the level of information, the higher the capacity for decision on the most efficient governance structure.

That relationship between scope and governance can be illustrated with the poultry market from the state of Paraná, Brazil. Three large groups direct their products (whole poultry and poultry cuts for the domestic market; whole poultry and poultry cuts for the international market; processed poultry for the domestic market). Based on Silva and Saes (2004) it is possible to see that companies with the largest scope are the most integrated ones (hierarchic ones), which corroborates the previous statement (Equation 3 and Figure 2). 
Figure 2_ Changes in total cost, governance cost and production cost based on the economy of scope

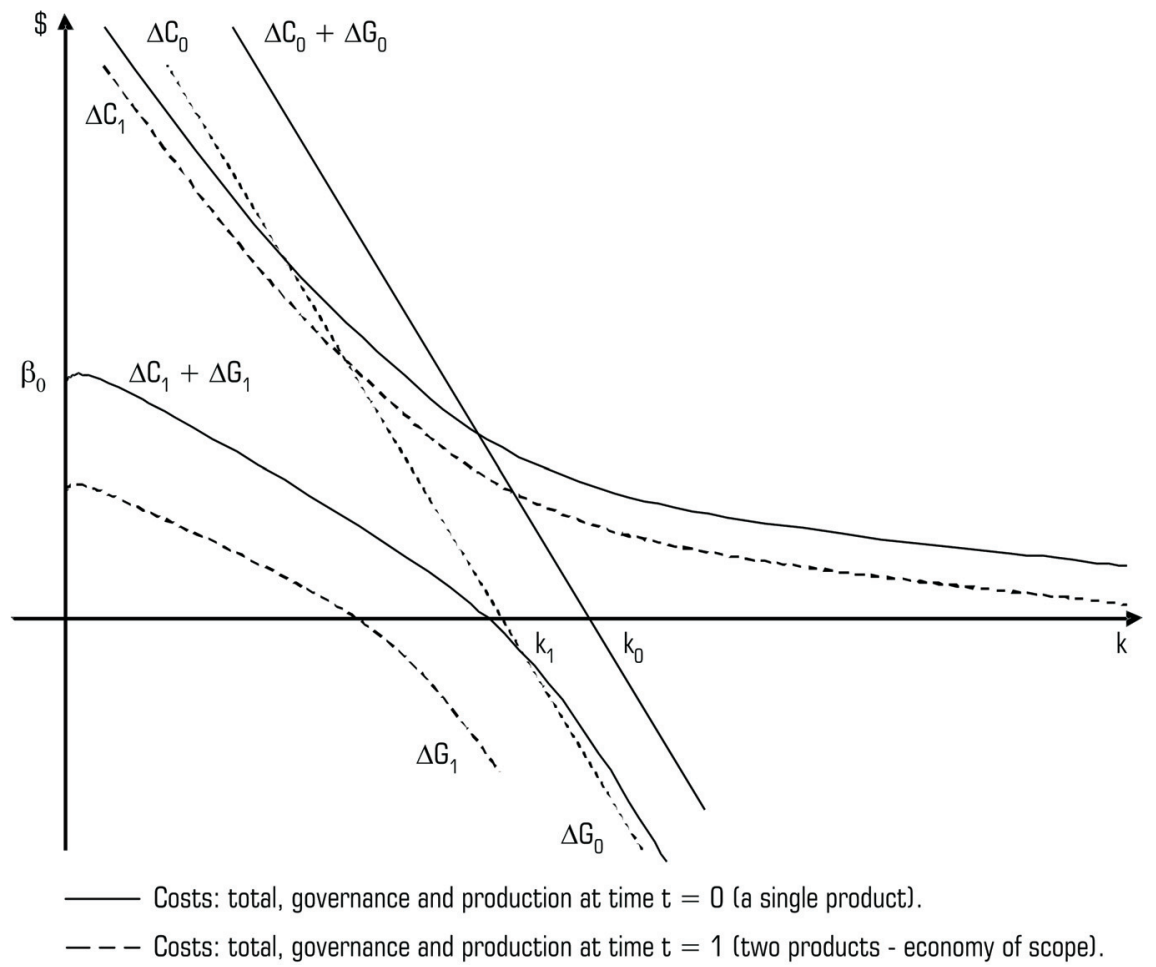

Source: The authors.

It is important to emphasize that despite the fact that the scale economy is a horizontal relationship (gains stemming from the diversification of production) it may be a source of optimization of governance costs and may alter the vertical relationship (governance structure).
In serving distinct markets with the same production technology, bureaucratic costs are optimized and the total for different products and markets become less than the sum of all individual parts (if the firm served each market separately). This optimization may reduce the governance cost for 
each product produced below that of a single product. Such a reduction in governance cost may make viable the change in the governance structure from market to hierarchical, increasing the firm's control, reducing risk, without significant changes in costs.

As firms increase their scale of supply there is a tendency to reduce mean bureaucratic costs, which, despite keeping the same technology and specificity of assets, makes changes in the type of governance structure viable.

In fact, horizontal decisions, like the increase of supply scale, may have vertical impacts, from the governance structure perspective. For Williamson, this alternative was not considered because it did not contemplate the possibility to increase the potential of scale economies, in other words, producing different products utilizing the same technology. In making this scale economy viable, a productive chain has different commercial ties (serving different markets with the same technological structure) and reduces its mean bureaucratic costs. The larger the variety of production and commercialization utilizing the same production technology, the smaller the mean bureaucratic cost and the larger the incentives for the relationships in the chain to tend towards hierarquical and away from market relationships, seeking to reduce risk at a lower cost (mean bureaucratic cost).

Another aspect referring to the strategic definition of the type of governance derives from the demand side and of the interdependence between production and commercialization.

\section{2_ Interdependence Between Production and Commercialization Strategies}

In addition to the economy of scope relative to production costs, it is possible to have an economy based on the capacity to serve different markets, thus reducing risks and maximizing opportunities. In this sense, profitability would be distributed through the different products commercialized, and, as compensation, a differentiated governance structure would be required.

Using the poultry industry example, Silva and Saes (2004), by means of an econometric model, have proven that there is a correlation between the dynamics of the internal and the external market, even though they are distinct, which strongly influence the strategy of the firms. The 
decision to migrate from one market to another depends on the comparison across different structures between the cost of information (transaction) to carry out that strategy and the revenues received when sales are made in this new market. If the estimated cost is lower than the projected gains, the firm would incur in such costs to enter the national or international market, or even the market of processed foods.

The average profit of firms can be expressed through the following relations:

$L_{1}=\frac{(\text { Pint } \times \text { Qint })-\left(C f r_{1}+C G_{1}\right)}{Q^{i n t}}$

$L_{2}=\frac{(\operatorname{Pint} \times \text { Qint })+\operatorname{Pext}(\text { tcam }) \cdot \operatorname{Qext}-\left(C f r_{2}+C G_{2}\right)}{Q_{\text {int }}+Q_{\text {ext }}}$

$L_{3}=\frac{(\text { Pint } \times \text { Qint })+\text { Pext }(\text { tcam }) \cdot \text { Qext }+ \text { Pproc.Qproc }-\left(C f r_{3}+C p r o c+C G_{3}\right)}{\text { Qint }+ \text { Qext }+ \text { Qproc }}(6)$

where: Pint $=$ is the price in the domestic market, which is a function of the international price;

Qint $=$ is the quantity sold in the domestic market; Pext $=$ is the price in the external market, which is a function of the currency exchange rate;
Qext $=$ is the quantity sold in the external market;

$C f r=$ is the production cost;

$C G=$ is governance cost and;

Cproc $=$ is the cost of processed product;

Pint and Pext $=$ are market data.

Concerning governance, empirical research has shown that the firms integrated by contract, a trend among all exporting groups, guarantee a less variable price for producers than firms purchasing inputs on the spot market (Silva and Saes, 2004). A formal contract with the processing segment and with the distribution channel decreases the level of uncertainty. The offer of poultry in the internal market, in turn, depends on international prices that are functions of the exchange rate. Thus, considering a constant demand in the internal market, the profit of the $\mathrm{L}$ firms depends on the poultry prices in the international market.

Since there is an inter-relation between the national and international market, and considering the price in the international market as given, the Brazilian firms are also price takers and the demand is inelastic at external market price. However, if this price is inelastic in the international market, any 
alteration in that market will significantly affect the internal market. Non-exporting firms have their strategies subject to the behavior of the internal market, and, to a certain extent, of the market of processed foods. Thus, this increased complexity and difficulty to access information (please read markets) would lead to different governance structures in the chain.

Innovative firms (market leaders) and most imitative exporting firms direct their in natura produce to the external market; in the internal market they compete for the processed goods, which have another pattern of competition and a more inelastic demand when compared to the in natura produces, and are less dependent on the international price dynamics.

In addition, exporters are not interested in competing in the Brazilian whole poultry market. Their main reasons include: high price volatility, strong and, at times, unfair competition, such in the case of higher than permitted levels of moisture in the poultry. This inter-relation among national markets, international markets and different types of products (whole poultry, meat poultry and processed foods), allied to the competitive characteristics of the whole poultry market, enable the continuity of slaughtering firms, in this market, with a smaller scale of production and a less vertical governance structure.

Regarding this aspect, Williamson (1985, p. 125) comments on the influence of the power of the market in the definition of the governance structure. To corroborate his statement, he presents the results of Porter and Livesay's study, in which they observe that

\section{the incidence of oligopoly and large size was much less frequent among manufacturers that did not integrate forward than among those that did.}

Another example was developed by Muris, Scheffman and Spiller (1992) for the soft drink industry, mentioned in section 2 herein. The governance structures observed in both of the two largest firms, Coca-Cola and Pepsi-Cola, in the North-American market have undergone an important change in the last thirty years. According to the authors, the changes that resulted in vertical integration with the distributing companies were motivated by strategic considerations, given the significant market changes, particularly regarding the growth in the size of the companies' clients. The efficiency in the geographically dispersed production decreased due to the economic cost 
associated with the relative

concentration of the buyers and the need for a market strategy extrapolating the regional distribution of the bottlers. During the first years of the industry, a centralized control of these operations was impossible due to the difficulty in monitoring and communicating.

In that manner, the interdependency between the form of commercialization and the structure of production makes the governance relationship in the production chain dependent not only on the specificity of assets, but also on the way that production and commercialization are linked.

The efficiency of the firm, throughout its production chain, is linked to the relationship between the productive phase, discussed by Williams, and the way in which the production is commercialized, which is not considered by that author.

This peculiarity denotes that besides technology, the governance structure throughout the chain can be defined from the firms' production and commercialization strategies.

In this situation, the economy of scope assumes a determining status, because it develops alternatives for placement of production, reducing mean bureaucratic costs. Horizontal decisions (economy of scope production mix and/or production channel, as exemplified in the poultry chain), in this situation, assume a determining status in a vertical relationship (definition of the more hierarchical governance structure).

Technology is, therefore, an important decision variable in the governance structure, but not the only one, as Williamson pointed out. Information, institutional path dependency, market and production strategies, are also relevant variables to understand the definitions of governance structures in a chain, allowing for the coexistence of different structures with the same production technology or specificity of assets.

\section{Final considerations and new works proposal}

This article presented a theoretical discussion of the factors determining governing structures based a transaction cost approach. Transaction Cost Economics points to a trend showing the existence of only one governance structure: the most efficient. However, as discussed herein, different governance structures can be associated with 
different market strategies. Structures basically differ when observed in terms of their production destination.

Instead of analyzing only the asset specificity to evaluate the trend to obtain a high governance cost and a more hierarchic structure, it is necessary, based on the argumentation developed, to bear in mind: the markets the firms serve (size, level of information necessary, type of product, quantity of competitors and consumers); inter-relationship among the markets (dependence on the different markets served with the same production technology); degrees of uncertainty.

The first issue is strategic for the firm, since it defines the market the firm wishes to participate in. That decision will certainly be limited by its capacities, such as its control over the resources. Nevertheless, the firm will evaluate the cost (investment) and the benefit (capital return) based on the characteristics of the market (size, quantity transacted and quantity/power of competitors and consumers). Thus there can be firms with the same production technology serving different markets for strategic decisions. The particularities of each market can allow each firm to continue surviving with different strategies, which would also allow for the coexistence of different governance structures.

The inter-relationship among markets can be one of the conditionings for the firms to survive without adopting equal strategies. When they participate in differentiated markets, however strongly inter-related they are, they will be competing in different competition patterns. Thus, if strongly inter-related markets are served by the same production technology, firms will have more possibilities for competition and for strategies. In this case, the coexistence of governance structures is feasible, such in the case illustrated by the poultry chain, in which although the domestic and the international market are strongly inter-related, each manages to survive with different governance structures because there is a is strong relation between the markets and thus alternatives for commercialization that open space for different groups of firms to compete in.

Therefore, besides the specificity of the assets, other reasons determine the type of governance structure. This work draws theoretically on the discussions and examples from Joskow (1993) and Muris, Scheffman and Spiller 
(1992), to conclude that, despite the same degree of asset specificity among the firms, the coexistence of different governance structures is possible and occurs as a result of the firms' strategies concerning target markets. As discussed in the fourth section herein, the efficiency in Williamson and Barzel's views must be particularized according to the type of demand the firm meets. Thus it is possible to have the same production system meeting different demands, which makes the existence of more than one type of efficient structure possible.

Williamson's analysis departs from a perspective of comparative static to propose a model relating the degree of specificity of the assets to the costs of the governance modes. However, it can be observed that besides the assets, the same chain can have different strategic directions, which makes different governance structures viable. This issue trace its roots to the concept of economic efficiency, which considers that the relative efficiency between assets and transaction costs proposed by Williamson is the productive one, whereas there is an allocative efficiency that interferes in the governance structure and in the transaction cost based on the market strategy. This allocative efficiency is herein understood as the gain obtained through a better allocation of resources, arising, mainly, in situations of economies of scope. Thus, the prevailing structure would be a ratio of the productive and the allocative efficiency, allowing for the coexistence of structures with the same asset specificity.

In order to prove the conclusions of this work, a comparative study of different market is suggested as a proposal of continuity. Thus it will be possible to minimize the limitations raised by Joskow (1993) in empirical evidence, based on the possibility of interpretation and analysis of the determining factors of the definition of governance structure, taking into consideration the theoretical basis herein discussed. 


\section{References}

AZEVEDO, P. F. de. Integração vertical e barganba. 1996. Tese (Doutorado em Economia) Faculdade de Economia e Administração, Universidade de São Paulo, 1996.

BARZEL, Y. Economic analysis of property rights. Cambridge: University Press, 1997.

BROUSSEAU, E.; FARES, M. Incomplete contracts and governance structures: are incomplete contract theory and new institutional economics substitutes or complements? In: MÉNARD, C. (Ed.). Institutions, contracts and organizations: perspectives from new institutional economics. Edward Elgar Pub., UK: 2000. p. 399-421.

COASE, Ronald $\mathrm{H}$. The nature of the firm. Economia, v. 4 p. 386-405, Nov. 1937.

\section{COASE, R. Industria} organization: a proposal for research. In: FUCHS, V. R. (Ed.) Policy issues and research opportunities in industrial organization. New York: National Bureau of Economic Research, 1972. p. 59-73.

DEMSETZ, $\mathrm{H}$. The theory of firm revisited. In the nature of the firm: origins, evolution, and development. In: WILLIAMSON, O. E.; WINTER, S. G. (Org.) The nature of the firm: origins, evowtion and development. Oxford/USA: Oxford University Press, 1993. p. $159-178$.
ESPINO, J. A. Institucionesy Economia: una introducción al neoinstitucionalismo económico. México: Fondo de Cultura Económica, 1999

HART, O. Firms contracts and financial structure. Oxford/USA Clarendon Press, 1997.

JANK, Marcos Sawaya. Competitividade do agribusiness brasileiro: discussão teórica e evidências no sistema carnes. 1996. Tese (Doutorado em Economia) - Faculdade de Economia e Administração, Universidade de São Paulo, 1996.

JOSKOW, P. Asset specificity and the structure of vertical relationships: empirical evidence. In: WILLIAMSON, O. E. WINTER, S. G. (Org.). The Nature of the firm: origins, evolution, and development. Oxford/ USA: Oxford University Press, 1993. p. 117-137.

KLEIN, B.; CRAWFORD, R. G.; ALCHIAN, A. A Vertical integration, appropriable rents, and the competitive contracting process. The Jornal of Law \& Econmics, v. XXI, n. 2, out./dez., 1978.

LANGLOIS, R. The entrepreneurial theory of the firm and the theory of the entrepreneurial firm. Paper for the conference "Why do entrepreneurial firms exist?". Ohio State University, October, p. 27-29, 2005.
MÉNARD, C. Enforcement procedures and governance structures: what relationship? In: MÉNARD, C. (Ed.). Institutions, contracts and organizations: perspectives from new institutional economics. Edward Elgar Pub., UK: 2000. p. 234-253.

MURIS, T.; SCHEFFMAN, D. T.; SPILLER, P. Strategy and transaction costs: the organization of distribuition in the carboneted soft drink industry. Journal of Economics \& Management Strategy, v. 1, n. 1, spring, 1992.

NORTH, Douglass C. A revolution in economics. In: MÉNARD, C. (Ed.). Institutions, contracts and organizations: perspectives from new institutional economics. Edward Elgar Pub., UK: 2000. p. 37-41.

NORTH, Douglass C Understanding the process of economic change. USA: Princeton University Press, 2005.

SILVA, C. L.; SAES, M. S. M. Competitividade e tipos de estruturas de governança: a avicultura de corte paranaense à luz da nova economia institucional. In: SEMINÁRIO ITINERANTE SOBRE A ECONOMIA PARANAENSE (2.: 2004: Toledo, Paraná) Toledo-PR: Ipardes, 2004

WILLIAMSON, O. E. Markets and hierarchies: analysis and antitrust implications. New York: Free Press, 1975
WILLIAMSON, O. E. The economic institutions of capitalism. New York: The Free Press, 1985.

WILLIAMSON, O. Comparative economic organization: the analysis of discrete structural alternatives. Administrative Science Quarterly, New York, v. 36, p. 269-296, June 1991.

WILLIAMSON, O. E. Mechanisms of governance. New York: Oxford University Press, 1996.

WILLIAMSON, O. E. WINTER, S. G. (Org.). The nature of the firm: origins, evolution, and development. Oxford/USA: Oxford University Press, 1993.

WINTER, S. G. On coase, competence, and the corporation. In: WILLIAMSON, O. E.; WINTER, S. G. (Org.) The Nature of the firm: origins, evolution, and development. Oxford/USA: Oxford University Press, 1993. p. 179-195.

ZYLBERSZTAJN, D. Estruturas de governanca e coordenacão do agribusiness: uma aplicação da nova economia das instituições. 1995.

Tese (Livre docência) - Faculdade de Economia e Administração, Universidade de São Paulo, 1995.

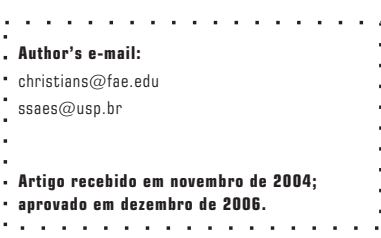

